\title{
Life of Max Pfannenstiel: A Reflection of the Twentieth Century in the Biography of a Scientist
}

\section{Max Pfannenstiel’in Yaşam Öyküsü: Yirminci Yüzyılın Bir Bilim Adamının Biyografisindeki Yansıması}

Andreas Hoppe, Unter und Oben - Max Pfannenstiel im 20. Jahrhundert - Katholik mit jüdischen Vorfahren, Geologe und Bibliothekar, im Exil und bei der Wehrmacht, Ordinarius and Rektor, Freiburger Beiträge zur Wissenschafts und Universitätsgeschichte Neue Folge, no. 9, Verlag Karl Alber, Freiburg/München, 2021, 313 pp. Hardbound small 8vo, Preis: $€ 50.40$

ISBN : 978-3-495-49205-5

A. M. Celâl Şengör ${ }^{1}$ (D)

Prof. Dr., ITÜ Maden Fakültesi, Jeoloji Bölümü ve Avrasya Yerbilimleri Enstitüsü, İstanbul, Türkiye

ORCID: C. ş. 0000-0001-8767-8831

Corresponding author / Sorumlu yazar:

A.M. Celâl Şengör, ITÜ Maden Fakültesi, Jeoloji Bölümü ve Avrasya Yerbilimleri Enstitüsü, İstanbul, Türkiye

E-mail/E-posta: sengor@itu.edu.tr

Submitted/Başvuru: 23.04.2021 • Accepted/Kabul: 18.05.2021 • Published online/Online yayın: 05.07.2021

Citation/Atıf: Şengör, A. M. Celâl. “Life of Max Pfannenstiel: A Reflection of the Twentieth Century in the Biography of a Scientist."Osmannlı Bilimi 
The versatile and laureate geologist Professor Andreas Hoppe (1948-), whose contributions range from Precambrian and Quaternary geology, through environmental geology to the geology of natural resources has now enlarged his range of interest to include the history of geology by publishing a wonderfully detailed biography of his former institute director Professor Max Pfannenstiel (1902-1976) in Freiburg im Breisgau. Just by looking at the full title of the book discloses a partial reason for publishing this biography: Unter und Oben - Max Pfannenstiel im 20. Jahrhundert - Katholik mit jüdischen Vorfahren, Geologe und Bibliothekar, im Exil und bei der Wehrmacht, Ordinarius and Rektor (=Below and Above - Max Pfannenstiel in the $20^{\text {th }}$ century - Catholic with Jewish ancestors, geologist and librarian, in Exile and in the Wehrmacht ${ }^{1}$, ordinarius ${ }^{2}$ and rector $^{3}$ ).

Pfannenstiel's life is almost a summary of the $20^{\text {th }}$ century in miniature. He was an Alsacian, when Alsace belonged to Germany between 1871 and 1919. His family belonged to the Altdeutschen group in Alsace, i.e., to those who had moved into Alsace after its annexation by Germany in 1871. After France reannexed it in 1919, all the 'Altdeutschen', including the Pfannenstiel family, were driven out. Unfortunately for Max Pfannenstiel, his maternal grandfather was Jewish, so in 1933, when the Nazis came to power, he was classified as a 'hybrid second grade' and lost his position as the librarian in the University of Freiburg. Before that he had received a PhD under the direction of Wilhelm Salomon (after 1914 as Salomon-Calvi: 1868-1941), one of the most highly respected geologists in Europe and a very early convert to Wegener's theory of continental drift.

In 1934, his teacher Salomon-Calvi, who was born Jewish, but later converted to Catholicism, and thus had lost not only his position in the university as the geology ordinarius after 37 years of service, but also his rights as an honorary citizen of Heidelberg because of the racial policy of the Nazi Germany, emigrated to Turkey for a position offered to him as professor of geology in the newly established Yüksek Ziraat Enstitüsü (=Higher Institute of Agriculture) in Ankara. In 1938, Salmon-Calvi secured a position as the librarian of the Yüksek Ziraat Enstitüsü for the now jobless Pfannenstiel, and despite the best efforts of the Nazi government to hinder his emigration, Pfannenstiel managed to get permission to leave Germany to come to Turkey.

Pfannenstiel's Turkish years are described by Hoppe in a special chapter of his book (pp. 76-88), which is translated by Professor Atilla Bir in this issue, with the permission of the publisher and the author. In 1941, after Salomon-Calvi's death, Pfannenstiel returned

1 I.e., the German military (1933-1945) consisting of the army (das Heer), navy (die Kriegsmarine) and the air force (die Luftwaffe).

2 Literally an 'ordinary professor' used, in the German-speaking countries, for the holder of an academic chair ( $\mathrm{C} 3$ or $\mathrm{C} 4$ profesorship). If there are other professors in the personnel of the same chair, they are usually referred to as 'titular professors'.

3 In the German-speaking countries usually as rector magnificus, the top administrator of a university. 
to Germany as the opportunities for research in Turkey seemed limited. After his return to Germany, the Nazi state made use of his geological skills as a military geologist.

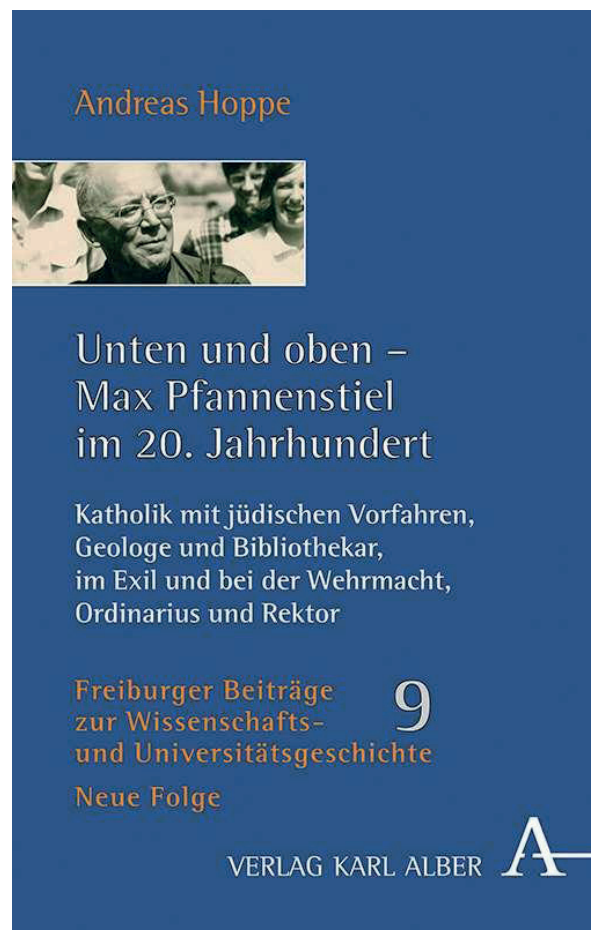

After the war, Pfannenstiel returned to Freiburg and worked with his colleagues to recreate the totally ruined old institute. He was appointed as the ordinarius for geology in 1947, two years later he became the dean of the mathematics-natural science faculty and later, in 1953, he finally became the rector of the university, twenty years after he had been expelled from it on racial grounds! In 1970, Pfannenstiel retired from his position and passed away on the first of January 1976 in Freiburg not too far away from where he had been born 74 years earlier, now across the border with France.

Pfannenstiel certainly was not one of the great geologists of the twentieth century. He contributed to geology in important ways, however, by his research in the Precambrin terranes, in tectonics, both in Germany and in Turkey, in Quaternary geology around the Eastern Mediterranean and even in prehistory. Had he been given the opportunity of a regular professional life, there is little doubt that he could have done more. Outside research he did much to bring geological teaching and research back on their feet after the devastating World War II, that ruined his homeland not only physically, but also intellectually. He worked in various scientific bodies not only in his native Germany, but also abroad and he even founded one in Freiburg. 
Hoppe does a superb job in narrating Pfannenstiel's scientific contributions. At the end of the book there is a complete list of Pfannenstiel's scientific writings, which, despite the rather unfavourable circumstances for much of his life, amounts to 134 publications. Hoppe also listed the lectures Pfannenstiel gave and the field excursions he led. The book also has a long and very relevant list of references and an index of personalities mentioned in the book.

Is Hoppe's biography of Pfannenstiel important? I think it is extremely important as it relates the life and the endeavours of a dedicated geologist in a century of disasters and at a time geology had stagnated world-wide, during an interval I elsewhere called the 'Dark Intermezzo'. In his socially turbulent and intellectually stagnant environment, Pfannenstiel managed to keep a very broad palette of interests, published papers many of which were important for the areas to which they pertained. He made interest in the history of geology fashionable again and recreated the Geologenarchiv in Freiburg, originally founded by Erich Haarmann, but regrettably destroyed during World War II.

Pfannenstiel was an admirable man. Not every geologist has to be a Suess or an Argand or a Cloos or a Tuzo Wilson. In his more modest way, largely forced on him by the worst century in human history, he nevertheless made important contributions to geology itself and to the institutions necessary to keep it alive. We are all grateful to Professor Hoppe for this wonderfully researched biography of an important geologist and his world at a time of social and scientific transformations, the speed of which had not been hitherto experienced by mankind. 